\title{
成人における大腿直筋とハムストリングスの 伸張度について
}

佐賀医科大学整形外科

忽 那 龍 雄* ・渡 辺 英 夫**
東

東和大学工学部電子工学科

岩 橋 正 国****

\section{Extensibility of the Quadriceps and Hamstrings Muscles in Adult}

by

\author{
T. Kutsuna, H. Watanabe and I. Higashi \\ Division of Orthopedic Surgery, Saga Medical School, Saga \\ M. Iwahashi \\ Department of Electronic Engineering, Towa University, Fukuoka
}

\begin{abstract}
Extensibility of the rectus femoris and hamstrings muscles in 1788 healthy adult (946 males and 842 females) was measured and the results were statistically analysed.

Extensibility of the rectus femoris (the average angle of the buttock elevation phenomen) in males was $123.9^{\circ} \pm 17.01^{\circ}$ on the right leg and $122.2^{\circ} \pm 19.77^{\circ}$ on the left leg. In females was $135.9^{\circ} \pm 9.42^{\circ}$ on the right leg and $135.5^{\circ} \pm 11.01^{\circ}$ on the left leg.

Extensibility of the hamstrings muscle (the average angle of the straight leg raising test) in males was $78.7^{\circ} \pm 9.70^{\circ}$ on the right leg and $79.0^{\circ} \pm 9.94^{\circ}$ on the left leg. In females was $85.7^{\circ} \pm 8.48^{\circ}$ on the right leg and $87.3^{\circ} \pm 8.38^{\circ}$ on the left leg.

Both muscle extensibility in females was higher than in males. Also, there was a high correlation between the right leg and the left leg.
\end{abstract}

\section{はじめに}

大腿直筋とハムストリングスは互いに拮抗する働き をむち股関節並びに膝関節の運動性に関与する 2 関節 筋である．乙れら筋肉の伸張度の評価が日常の診断に 利用され問題となることは少なくない. 即ち，尻上り 現象角度としてあらわされる大腿直筋の伸張度は，大 腿直筋拘縮症の診断に際して問題となり，ハムストリ ングスの伸張度は, 腰部椎間板ヘルニア時の下肢伸展 挙上試験を評価する上に問題となろう.

また，大腿直筋伸張度については，小児では，筋拘 縮症という観点から多くの報告があり，若松は ${ }^{6)}$ 尻上 り角度で 45 度未満になると路容異常, 正座が出来な

* 助教授, **教授, $* * *$ 助手, $* * * *$ 講師
いなどの障害をみるという，しかし，成人ではどうで あるのか不明であり, 私達は, 第 59 回西日本 整形災 害外科学会において，20才から49才までの成人男性 に打ける大腿直筋とハムストリングスの伸張度につい て報告した ${ }^{3)}$.今回は，年令を 20 才から 69 才までと して成人女性における両筋の伸張度を調査したので, 50 才から 69 才までを追加した男性における両筋の伸 張度と比較検討し報告する。

\section{対象並びに方法}

調査対象は，健康診査実施時に来晾した陸上自衛隊 員並びに佐賀地区住民のうち, 股関節や膝関節に障害 のない 20 才から 69 才までの男性 946 名, 女性 842 名 計 1,788 名の両下肢についてである. その内訳は表 
表 1 調 査 対 象

\begin{tabular}{c|c|c|c|c|c|c}
\hline \hline 年命 & 20 代 & 30 代 & 40 代 & 50 代 & 60 代 & 計 \\
性別 & & & & & \\
\hline 男 性 & $356^{\circ}$ & $142^{\circ}$ & $324^{\circ}$ & 72 & 52 & 946 名 \\
女 & 60 & 163 & 294 & 242 & 83 & 842 名
\end{tabular}

○第59回西日本整災発表

\section{1) に示した.}

調査方法は, 対象肢について, 大腿直筋伸張度の指 標としていわゆる尻上り現象開始角度 (B.E.P) を, 八ムストリングス伸張度の指標として下肢伸展挙上角 度（S.L.R）を測定した.

尻上り角度並びに下肢伸展挙上角度の測定に関して は，床面を 0 度とし，前者は腹臥位で他動的に膝関節 を屈曲してゆき股関節が屈曲し始める時の膝関節角度 を1)，後者は仰臥位で骨盤を固定し他動的に膝伸展位 の下肢を抵抗なくもち挙げ得る角度とした。

これらの測定結果をもとに, 両筋の平均伸張度並び に標準偏差値を求め, 拘縮とみなされる臨界值を推定 して拘縮頻度を調べた. さらに，両筋について左右 差, 年代差, 性差があるから゙うか, 並びに大腿直筋伸 張度と八ムストリングス伸張度との間に関連性がある かどうかについて, 平均值の差の有無, 相関関係の有 無など統計学的に検討を加えた.

\section{結果}

I ．大腿直筋伸張度について

1）成人男性についての伸張度

成人男性 946 名 1,892 肢について測定した尻上り角 度の分布は, 最低 20 度, 最高 160 度であり, 30 度以 下 3 肢, 31 60 度 18 肢, 61 90 度 85 肢, 91 130度 1,171 肢，131 135 度 138 肢，136 度以上 477 肢で あ った. 即ち, 大多数肢は 91 度以上であり，91〜130度 に区分されるあのが 1, 892 肢中 1, 171 肢約 $62 \%$ 之最 あ多い，しかし，90 度以下のあのあありその頻度は 1, 892 肢中 106 肢約 $6 \%$ であった（図 1).

これら尻上り角度の平均值並びに偏差値は, 右下肢 123.9 度土17.01 度, 左下肢 122.2 度 \pm 19.77 度であ り, 右と左下肢との間には, 平均值に有意差はなく, 単相関係数 0.877 を示す高度に有意な相関が認められ た.

また，各年代別にみた平均尻上り角度は，20 代：右 下肢 125.0 度 \pm 16.64 度・左下肢 123.3 度 \pm 12.29 度,

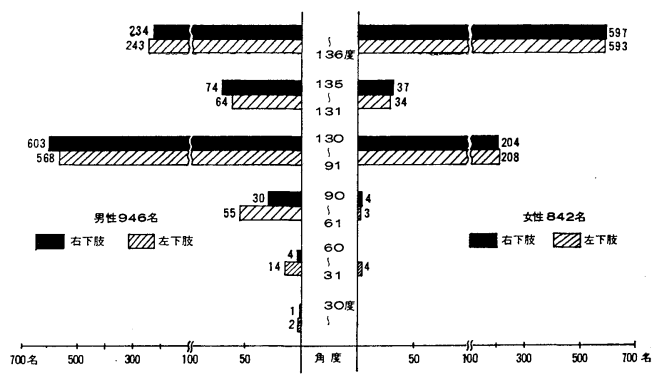

図 1 尻上り角度分布

成人男性では91〜130 度に区分されるものが最む 多く，成人女性では 136 度以上に区分されるもの が最も多い。

30 代: 右 121.1 度 \pm 17.27 度 $\cdot$ 左 117.7 度士21.98度, 40 代：右 124.2 度士16. 39 度 - 左 122.9 度士18.94度, 50代：右 124.1 度土19.17 度 - 左 121.2 度土18. 26 度, 60 代：右 121.2 度 \pm 18.26 度・左 121.7 度士18. 39 度 であり，20 代から 60 代までの各年代間の平均值に 有 意な差はなかった。

2）成人女性についての伸張度

成人女性 842 名 1,684 肢について測定した尻上り角 度の分布は, 最低 40 度, 最高 160 度であり，30 度以 下 0 肢, 31 60 度 4 肢, $61 \sim 90$ 度 7 肢, 91 130 度 412 肢, 131 135 度 71 肢, 136 度以上 1, 190肢であっ た. 即ち, 大多数が 91 度以上であり, 136 度以上に区 分されるものが 1, 684 肢中の 1,190 肢約 $71 \%$ と最 む 多い，そして 90 度以下のあのは 1,684 肢中 11 肢約 1 \%と僅かであった（図 1 ).

これら 尻上り角度の平均値並びに 偏差值は, 右下 肢 135.9 度 \pm 9.42 度, 左下肢 135.5 度 \pm 11.01 度であ り, 右と左下肢との間には，平均值の差に有意差はな く, 単相関係数 0.798 之高度に有意な相関が認められ た。 また，各年代別にみた平均尻上り角度は，20 代： 右下肢 136.6 度 \pm 6.22 度・左下肢 134.9 度 \pm 9.68 度, 30 代：右 136.4 度 \pm 8.23 度 - 左 136.3 度 \pm 8.56 度, 40 代：右 135.9 度土9.10 度 - 左 135.6 度土9.83 度, 50 代：右135. 9 度土9.65 度 - 左 135.2 度土12.19 度, 60 代：右 134.5 度士13.06 度 - 左 134.5 度士15.50度 であり， 20 代から 60 代までの各年代間に有意な差は なかった。

3）男女における伸張度の差

調查対象者における尻上り角度は, 総数の平均値並 びに 20 代から 60 代までの各年代の平均值に男女間で 


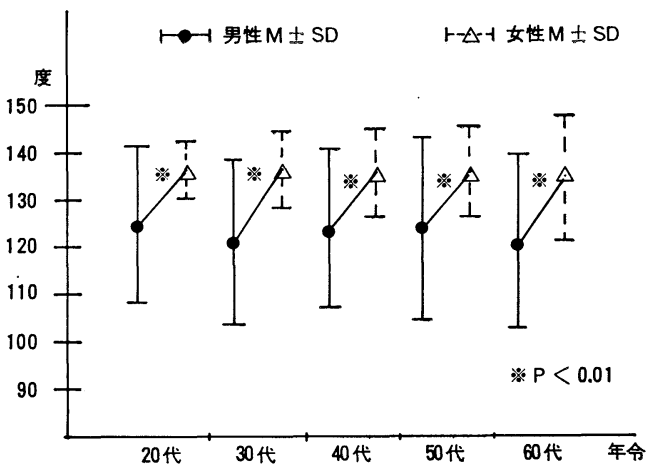

図2年代別, 性別平均尻上り角度（右下肢） 尻上り角度は男女差が有意であり女性が大きい值 を示す。また, 男女とも各年代間の平均角度に差 はみられない。

強い有意差があり, 女性の大腿直筋伸張度が大であっ た（図 2)。また，性別と尻上り角度は単相関係数右 下肢 0.395 , 左下肢 0.376 を示し, 有意な相関があっ た（ $\mathrm{p}<0.01)$. 即ち, 女性の角度が大きいといえる.

4）大腿直筋拘縮について

男女における尻上り角度の平均值から標準偏差値を 減じ，男性では尻上り角度 100 度以下，女性では 120 度以下を大腿直筋拘縮陽性と仮定した．その結果，大 腿直筋拘縮陽性者は，男性 では 946 名中 161 名 17.0 \%を占め, ての 161 名のうち 98 名 $(60.9 \%)$ が両侧 下肢陽性, 63 名 (39.1\%) が片側下肢陽性であり, 両 側下肢陽性者が多かった．また，片側下肢例では右側 22 名, 左側 41 名之左側下肢陽性者が多くみられた. さらに，年代別に みた拘縮率は 20 代 356 名中 42 名 (11.8\%)，30 代 142 名中 30 名 (21.1\%)，40 代 324 名中 60 名 $(18.5 \%), 50$ 代 72 名中 13 名 $(18.1 \%)$, 60 代 52 名中 16 名 $(30.8 \%$ ) であり，20 代と 30 代,

表 2 成人大腿直筋拘縮頻度 20 オ〜 69才

\begin{tabular}{l|c|c|c|c}
\hline \hline & \multirow{2}{*}{ 性別・対象者数 } & 拘縮人数 (\%) & 両側性 & \multicolumn{2}{|c|}{ 側 性 } \\
\hline 男性・946名 & 161名**(17.0) & 98名 & 22 & 左 \\
\hline 女性・842名 & 115名**(13.7) & 69名 & 22 & 24 \\
\hline
\end{tabular}

* B.E.P $100^{\circ} \geqq * *$ B.E.P $120^{\circ} \geqq$ ( )内 $\%$
20 代と 60 代に拘縮率の有意差があった $(\mathrm{p}<0.01)$. 一方，女性では拘縮陽性者が 842 名中 115 名 (13.7 \%) 飞認められ，115名のうち 69 名 $(60 \%)$ が両側 下肢陽性者, 46 名 (40\%) が片側下肢陽性者であり, 両側下肢陽性者が多い。また，片側例では右側 22 名， 左側 24 名であり左右ほぼ同じであった（表 2 )。さら に，年代別にみた 拘縮率は 20 代 60 名中 9 名（15.0 \%)，30 代 163 名中 21 名 (12.9\%)，40 代 294 名中 34 名 (11.6\%)，50 代 242 名中 36 名 (14.9\%)，60 代 83 名中 15 名 $(18.1 \%)$ であり, 各年代間の陽性率 に有意な差はなかった。

II. ハムストリングス伸張度について

1）成人男性についての伸張度

成人男性 946 名 1,892 肢について測定した下肢伸展 挙上角度の分布は, 最低 30 度, 最高 115 度であり, 30 度以下 1 肢, $31 \sim 50$ 度 11 肢, $51 \sim 70$ 度 517 肢, 71 $\sim 80$ 度 718 肢, $81 \sim 90$ 度 573 肢, 91 度以上 72 肢であ った. 即ち, 大多数が 51 度から 90 度までの間に分布 し, なかであ 71 度から 80 度に区分されるあのが最も 多く 1,892 肢中 718 肢約 $40 \%$ 占めた\%図 3 ).

これら下肢伸展挙上角度の平均值並びに偏差值は, 右下肢 78.7 度 \pm 9.70 度, 左下肢 79.0 度 \pm 9.94 度 で あり，右と左下肢との間には，平均值に有意差はな く, 単相関係数 0.864 之高度に有意な相関が認められ た。 また，各年代別にみた平均下肢伸展挙上角度は， 20 代: 右下肢 79.2 度士 10.14 度・左下肢 79.6 度士 10.22 度, 30 代: '右 79.3 度 \pm 9.20 度 $\cdot$ 左 79.9 度士 9.28 度, 40 代：右 79.4 度 \pm 9.05 度 $\cdot$ 左 79.7 度 9.65 度, 50 代：右 73.1 度 \pm 9.04 度 $\cdot$ 左 73.8 度士 9.30 度, 60 代：右 76.6 度 \pm 9.99 度 $\cdot$ 左 75.3 度士

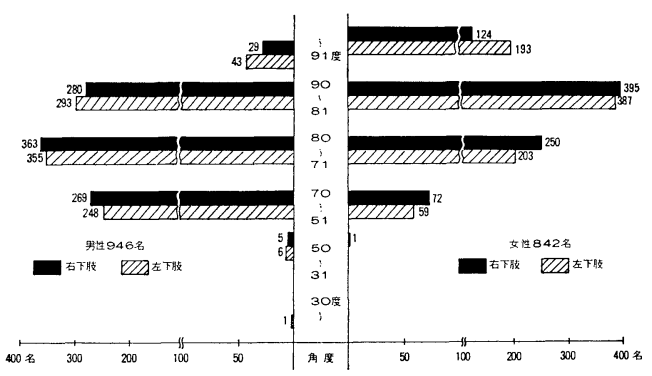

図 3 下肢伸展挙上角分布 男性では，大多数が51度から90度までに分布し， 女性では男性よりあ高く, 大多数が 71 度以上に分 布する。 
9.32 度であり, 50 代の平均值は 20〜 40 代より有意に 低い，しかしその差は 10 度以内であった.

2）成人女性についての伸張度

成人女性 842 名 1,684 肢について測定した下肢伸展 挙上角度の分布は, 最低 45 度, 最高 120 度であり, 30 度以下 0 肢, $31 \sim 50$ 度 1 肢, $51 \sim 70$ 度 131 肢, 71 $\sim 80$ 度 453 肢, $81 \sim 90$ 度 782 肢, 91 度以上 317 肢で あった. 即ち, 81〜90度に区分されるあのが最も多く 全肢のうち約半数を占め, しかも 91 度以上のものが 20\%も占め, 女性に打ける下肢伸展挙上角度の分布布 は男性よりあ高い(図 3 ).

これら下肢伸展挙上角度の平均值並びに偏差值は, 右下肢 85.7 度 \pm 8.48 度, 左下肢 87.3 度士 8.38 度で あり，右と左下肢との間には，平均值に有意差はな く, 単相関係数 0.847 と高度に有意な相関が認められ た. また, 各年代別にみた平均下肢伸展挙上角度は, 20 代：右下肢 80.7 度士 7.50 度 - 左下。肢 $82.6 \pm 7.50$ 度, 30 代: 右 84.8 度 \pm 9.04 度 - 左 85.9 度 \pm 8.48 度, 40 代: 右 85.6 度 \pm 8.36 度 $\cdot$ 左 87.1 度 \pm 8.31 度, 50 代: 右 87.7 度 \pm 8.18 度 - 左 89.2 度士8.41 度, 60 代： 右 85.9 度士7. 33 度・左 88.4 度士6.99 度であり, 20 代の平均值はすべての年代より有意に低かった. しか し，その差は 10 度以内である.

3）男女における伸張度の差

調査対象者に打ける下肢伸展挙上角度は, 総数の平 均值並びに 20 代を除く 30 代から 60 代までの各年代 の平均值に, 男女間で強い有意差があり, 女性の八厶

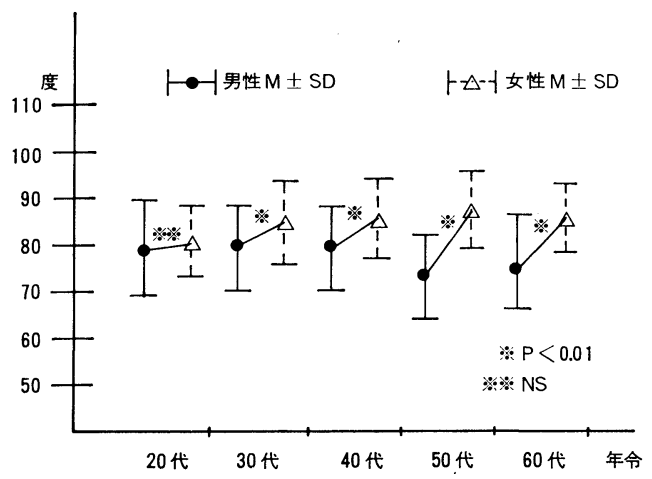

図4年代別, 性別平均下肢伸展挙上角度 (右下肢)

S.L.R 20 代を除き男女差があり女性が大きい 值を示す。また，50代の男性は20代〜40代の男性 より有意に低く，20代の女性は他の年代の女性よ りあ有意に低い。
表 3 成人ハムストリングス拘縮頻度 20〜69才

\begin{tabular}{r|c|c|c}
\hline \hline 性別・対象者数 & 拘縮人数 (\%) & 両側性 & \multicolumn{2}{|c}{ 片側 性 } \\
\hline 男性・946名 & 118 名* (12.5) & 83名 & $\frac{18 \text { 名 }}{\text { 左 }}$ \\
\hline 女性・842名 \\
\hline
\end{tabular}

$*$ S.L.R $65^{\circ} \geqq * *$ S.L.R $75^{\circ} \geqq$

ストリング伸張度が大であった（図 4)。また，性別 と下肢伸展挙上角度は, 単相関係数右下肢 0.359 , 左 下肢 0.408 を示し, 有意な相関があった $(\mathrm{p}<0.01)$. 即ち, 女性の角度が大きく, 男性の角度が小さい。

4) ハムストリングス拘縮について

男女に抬ける下肢伸展挙上角度の平均值から標準偏 差值を減じ，男性では 65 度以下，女性では 75 度以下 をハムストリングス拘縮陽性と仮定した. その結果， ハムストリングスの拘縮陽性者は，男性では 946 名中 118 名 (12.5\%) を占め, この118名のうち 83 名が 両側下肢陽性, 35 名が片側下肢陽性であり，両側下肢 陽性者が多かった．また，片側例では右側 18 名，左 側 17 名であり，左右ほぼ同数であった（表 3 ).さら に，年代別にみた拘縮率は 20 代 356 名中 42 名 (11.8 \%)，30 代 142 名中 12 名 (8.5\%)，40 代 324 名中 31 名 (9.6\%), 50 代 72 名中 20 名 (27.8\%), 60 代 53 名中 13 名 $(25 \%)$ であり，20 代から 40 代にくらべ 50 代並びに 60 代の拘縮率は有意に高かった（p< $0.01)$.

一方，女性では拘縮陽性者が 842 名中 111 名（13.2 \%) に認められ，111名のうち68名が両側下肢陽性, 43 名が片側下肢陽性であり, 両側下肢陽性者が多かっ た.また, 片側例では右側 30 名, 左側 13 名であり, 右側下肢陽性者が多くみられた（表 3 ). さらに，年 代別にみた拘縮率は，20 代 60 名中 18 名 (30.0\%), 30 代 163 名中 26 名 (16.0\%)，40 代 294 名中 40 名 (13.6\%)，50 代 242 名中 21 名 (8.7\%)，60 代 83 名 中 6 名 $(7.2 \%)$ であり, 20 代と 40〜60 代との間に 拘縮率の有意差があり、20 代の拘縮率が高かった（ $\mathrm{p}$ $<0.01)$.

III. 大腿直筋伸張度とハムストリングス伸張度との 相関性 
表 4 尻上り角度と下肢伸展挙上角度との相関係数

\begin{tabular}{|c|c|c|c|c|c|c|c|c|c|c|c|}
\hline & & 20 & 代 & 30 & 代 & 40 & 代 & 50 & 代 & 60 & 代 \\
\hline & S.L.R B.E.P & 右 & 左 & 右 & 左 & 右 & 左 & 右 & 左 & 右 & 左 \\
\hline 男性 & $\begin{array}{l}\text { 右 } \\
\text { 左 }\end{array}$ & $\begin{array}{l}0.006 \\
0.023\end{array}$ & $\begin{array}{l}0.007 \\
0.043\end{array}$ & $\begin{array}{l}0.151 \\
0.059\end{array}$ & $\begin{array}{l}0.104 \\
0.043\end{array}$ & $\begin{array}{l}0.214 * \\
0.205^{*}\end{array}$ & $\begin{array}{l}0.200 * \\
0.206 *\end{array}$ & $\left|\begin{array}{l}-0.114 \\
-0.068\end{array}\right|$ & $\mid \begin{array}{l}-0.044 \\
-0.004\end{array}$ & $\begin{array}{l}0.290 * * \\
0.292 * *\end{array}$ & $\begin{array}{l}0.191 \\
0.221\end{array}$ \\
\hline 女性 & $\begin{array}{l}\text { 右 } \\
\text { 左 }\end{array}$ & $\begin{array}{l}0.468^{*} \\
0.439^{*}\end{array}$ & $\begin{array}{l}0.334 * \\
0.290 * *\end{array}$ & $\begin{array}{l}0.429^{*} \\
0.393^{*}\end{array}$ & $\begin{array}{l}0.401 * \\
0.371 *\end{array}$ & $\begin{array}{l}0.173^{*} \\
0.171 *\end{array}$ & $\begin{array}{l}0.119 * * \\
0.151 *\end{array}$ & $\begin{array}{l}0.185^{*} \\
0.155^{* * *}\end{array}$ & $\begin{array}{l}0.253^{*} \\
0.321 *\end{array}$ & $\begin{array}{l}0.140 \\
0.083\end{array}$ & $\begin{array}{l}0.079 \\
0.039\end{array}$ \\
\hline
\end{tabular}

$* \mathrm{P}<0.01, \quad * * \mathrm{P}<0.05$ 相関あり

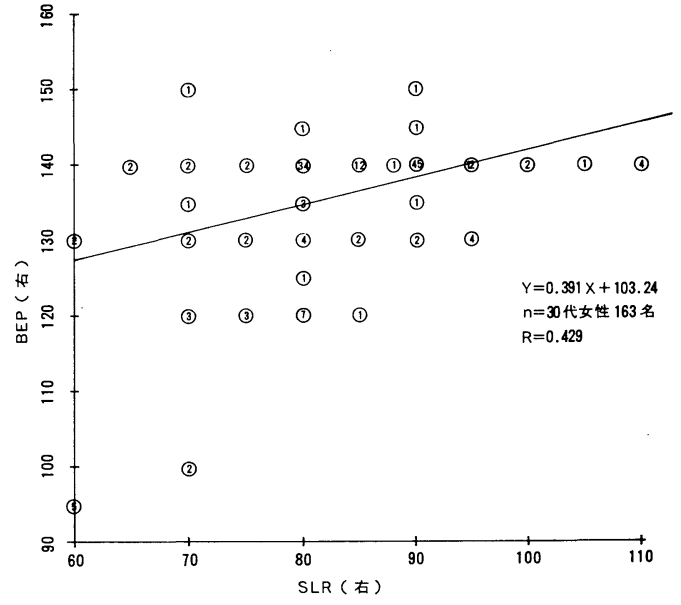

図 540 代の男悎, 20代加ら50代の女性では, B. E. P と S. L. R との間に有意な相関 がある $(\mathrm{P}<0.01)$ 。

大腿直筋とハムストリングスとの伸張度の相関関係 は，各年代別に尻上り角度と下肢伸展挙上角度との単 相関係数を求め，相関係数が有意であるかどうか $\mathrm{F}$ 分 布を使って検定を行なった。 その結果，男性では 40 代の対象者に扔いて有意水準 $1 \%$ で尻上り角度と下肢 伸展挙上角度との間に相関があった. 一方，女性では 60 代を除き 20 代から 50 代の対象者に有意水準 $1 \%$ (一部 $5 \%$ ) で相関があった（表 4, 並びに図 5 ).

$$
\text { 考察 }
$$

大腿直筋の伸展能力は股関節を 0 度に固定した場合 の膝屈曲可能角度（いわゆる尻上り角度）として，八 ムストリングスの伸展能力は膝関節を伸展位に固定し 股関節が屈曲できる角度（いわゆる下肢伸展挙上角 度）として表わされる. これらの正常可動域値は，日 本整形外科学会身体障害委員会4) の表示によれば, 前 者が腹臥位での膝屈曲角度と同義であり 130 度, 後者
が 90 度である. しかし，四肢関節可動域は，年令に よって一定の傾向はみられないが少なからず差をみる こと ${ }^{2) 7}$, 或いは多くの関節可動域に性差をみ女性の 方が大きい值を示すとと ${ }^{5}$ を指摘した報告が散見され る.

そこで，私達は大腿四頭筋拘縮症の䛦断に欠かせな い大腿直筋の伸張度について, 成人男女に打ける年令 差, 左右差があるかどうか, また大腿直筋の拮抗筋で あるハムストリングスの伸張度として表わされる下肢 伸展挙上角度との間に関連性があるかどうか検討を加 える必要があると考え, 健康成人について調查した. その結果, 平均尻上り角度は, 男性約 125 度, 女性約 135 度であり, 委員会表示の推定角度 130 度と大差な かった. また，少なくとあ 20 代から 60 代までの各年 代間の平均角度に有意差はみられず，さらに左右差も なかった，しかし，男女間には有意差があり，岡部 ら ${ }^{5)}$ の報告と一致した. 即ち, 成人に拈ける大腿直筋 の伸張度を評価するにあたっては, 男女差を考慮す心゙ きであることが指摘されよう.さらに，尻上り角度 は，40 代の男性並びに 20 代から 50 代までの女性につ いては下肢伸展挙上角度と有意な相関があり, 伸張度 の評価に際して, 拮抗筋相互の関連性も無視出来ない と思われた。

また，私達はすでに尻上り角度の正常值が定まって いるとはいいがたいととを考慮して, 健康人の平均值 から偏差值を减じ成人男性では 100 度以下が大腿直筋 による拘縮が考慮される角度としてよいのではないか との考えを述べた ${ }^{3)}$. 今回, 対象者の年代層を広げた 男性群と新たに女性群についての統計処理を行なった が，その臨界值は，男性が前回の報告と同様 100 度， 女性が 120 度と考えられた. そこで, これらの臨界值 以下のものを成人における大腿直筋の拘縮とみると, 男性では対象者の約 $17 \%$ ，女性では対象者の約 $14 \%$ にみられ，比較的高率である．また，成人における大 
腿直筋の拘縮は，尻上り角度が 45 度以下のものでも， 小児例の場合にみられる歩容異常, 正座が出来ないな どの訴えは，ほとんどみられなかった，乙のことも成 人例の特徵としてあげられ, 小児の拘縮症の予後を推 察する 1 つ参考資料となろう.

次に, ハムストリングスの伸張度は, 大腿直笳の拮 抗筋であるというほかに, 腰痛患者について行う坐骨 神経伸展試験（いわゆる S. L. R テスト）とも関連す る. 即ち, S. L. R テストに際して， ハムストリング スの過緊張による筋肉痛は腰椎に由来する下肢痛とま ぎらわしいことがあり, 健康人のハムストリングス伸 張度について知っておく必要がある. したがって, 今 回の調査結果から得られたその伸張度の臨界值が, 男 性 65 度以下, 女性 75 度以下とされること, 並びに右 と左下肢との伸張度に強い相関があったことは, 本検 査手技を評価するうえに参考とされよう.

\section{ま と め}

20 才から 69 才までの健康成人（男性 946 名, 女性 842 名）について，大腿直筋とハムストリングスの伸 張度を検討し, 以下の結果が得られた.

I . 大腿直筋伸張度

1. 平均尻上り角度は, 男性が右下肢 123.9 度士 17.0 度, 左下肢 122.2 度土 19.77 度であり, 女性が右 下肢 135.9 度士9.42 度, 左下肢 135.5 度士11. 01 度で あった。

2. 左右差はなく, 右と左下肢との伸張度に強い相 関があった.

3. 20 才代から 60 才代までの各年代間に伸張度の 差はなかった。

4. 男女差は有意であり, 女性の伸張度が大きかっ た.

5. 尻上り角度が男性 100 度以下，女性 120 度以下 を大腿直筋拘縮ありとすれば, 男性 946 名中 161 名 (約 $17 \%$ ), 女性 842 名中 115 名（約 $14 \%$ ）に認め られた。

II. ハムストリングス伸張度

1. 平均下肢伸展挙上角度は, 男性が右下肢 78.7 度士9.70 度, 左下肢 79.0 度士9.94 度であり, 女性が 右下肢 85.7 度 8.48 度, 左下肢 87.3 度 \pm 8.38 度
あった。

2. 左右差はなく, 右と左下肢との伸張度に強い相 関があった。

3. 50 代の男性之 20 代の女性の伸張度は他の年代 との間に有意差がみられた.

4. 男女差は 20 代の対象者を除き有意であり，女 性の伸張度が大きかった.

5. 下肢伸展挙上角度が男性 65 度以下，女性 75 度 以下をハムストリングス拘縮ありとすれば，男性 946 名中 118 名 (約 $13 \%$ ), 女性 842 名中 111 名（約 13 \%)に認められた.

III. 大腿直筋伸張度とハムストリングス伸張度との 関連性

大腿直筋伸張度は，男性では 40 代，女性では 20 代 から 50 代までのハムストリングス伸張度に有意な相 関があった $(\mathrm{p}<0.01)$.

\section{文献}

1）大腿四頭筋拘縮症委員会：大腿四頭筋拘縮症検 彰票：日整会誌. 54：829. 1980 .

2) 伊藤直栄: 老人の関節可動域の研究, 理 - 作 療法. 8: 440, 1974.

3）忽那龍雄・他：成人男性に打ける大腿直筋と八 ムストリングスの伸張度について, 西日本整災 誌, 29: 677, 1980.

4) 日本整形外科学会身体障害委員会：関節可動域 表示ならびに測定法, 日整会誌, 48：6 号巻頭, 1974.

5）岡部とし子・他：各年代における健康人の関節 可動域について, 総合リ八, 8: 41, 1980.

6）若松英吉・他：宮城県全学童生徒による大腿四 頭筋短縮症調查報告, 日本医師会雑誌, 75：505, 1976.

7）渡辺英夫 - 他：健康日本人に打ける四肢関節可 動域について，日整会誌，53：275，1979.

質 問長崎県立整肢療育園 䅖山富太郎 ハムストリングスの伸張に際して，骨盤の後傾がお こりはじめる角度を見分けるのは困難であるが，骨盤 を固定して測定するのかどうか.

\section{解 答}

骨盤を固定している. 